\title{
上部胆管癌の外科治療の検討
}

一特に，胆管切除の適応と限界について一

東京女子医科大学消化器病センター

$\begin{array}{llllllllll}\text { 高 田 } & \text { 忠 } & \text { 敬 } & \text { 今 } & \text { 泉 } & \text { 俊 } & \text { 秀 } & \text { 金 } & \text { 成 } & \text { 保 } \\ \text { 磯 辺 孝司 } & \text { 安 } & \text { 田 } & \text { 秀 } & \text { 喜 } & \text { 佐 } & \text { 藤 } & \text { 裕 } & \text { 一 } \\ \text { 宮 崎 } & \text { 典子 } & \text { 福 } & \text { 島 } & \text { 靖 } & \text { 彦 } & \text { 中 } & \text { 村 } & \text { 光 } & \text { 司 } \\ \text { 羽 生 富士夫 } & & & & & & & \end{array}$

\section{INDICATIONS AND LIMITATIONS OF THE SURGICAL RESECTION WITHOUT LOBECTOMY FOR CARCINOMA OF THE JUNCTION OF RIGHT, LEFT AND COMMON HEPATIC BILE DUCTS}

Tadahiro TAKADA, Toshihide IMAIZUMI, Seiho KANAYAMA, Koji ISOBE, Hideki YASUDA, Yuichi SATOH, Noriko MIYAZAKI, Yasuhiko FUKUSHIMA, Mitsuji NAKAMURA and Fujio HANYU

Department of Gastroenterological Surgery, Tokyo Women's Medical College

肝内胆管追跡切除を含む胆管切除を施行した上部胆管癌 9 例を中心に, 胆管切除の適応 と限界について検討した，肝内胆管の第 2 分岐まで癌進展が及ぶものに対しては, 肝内胆 管追跡切除も有効ではなく，払大右葉切除，左葉切除，内側前区域切除など肝切除を選択 適応することが必要である. 左右肝管に癌進展をみるも第 2 分牫に至らないるのに対して は, 肝内胆管追跡切除あるいは内側前区域切除の適応を考学る．総肝管に癌腫が存在する ものは, 胆管切除の最もよい適応であり，三管合流部以下の癌浸潤の有無によっては脺・ 十二指腸合併切除も適応となる. 廓清に関しては, リンパ節のみならず周囲神経束, リン パ管などを含め結合織の完全摘除が必要である. 又, 断端遺残のない上うに, 術中何回も 迅速標本を提出し，切除線を決定することも大切である. 門脈への直接浸潤に関しては， en block K門脈合併切除を行ならことる，成續向上になると考える.

\section{I はしめめ}

上部胆管癌は, その解剖学的位置関係により外科的 プローチが困難とされ，切除率す低く治療成績の不良の 分野とされてきだ．しかし，最近ではPTC（経皮的胆

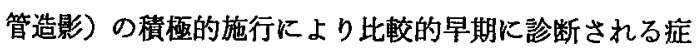
例も出現し，またPTCD（経皮的胆管ドレナーシ）の普 及により、これまでに Surgical Risk として問題とされ ていた閉塞性黄疸む解決の方向に進み”，次第に切除例 る增加し外科的関心が高まりつつある.

上部胆管癌の切除術式は，胆管切除にとどまるもの
$と^{334)}$ ，肝切除を行 $5^{5)-10)}$ あのの 2 つに大別され，その 適応・限界などについては, 今後更に追求される課題と なろ5. 今回は，これまでわれわれが行なってきた胆管 切除例を中心に，その適応，限界などを中心に検討を加 えてみた。

\section{II 対 象 例}

対象は，予後が明確となった1968年 1 月から1977年12 月までに切除した上部胆管癌（三管合流部より上部の胆 管癌） 9 症例である. 同期間に経験した上部胆管癌症例 は，57例で，切除率は15.8\%であった（表 1 ）。 
表 1 空嗄の占居部位と治療法

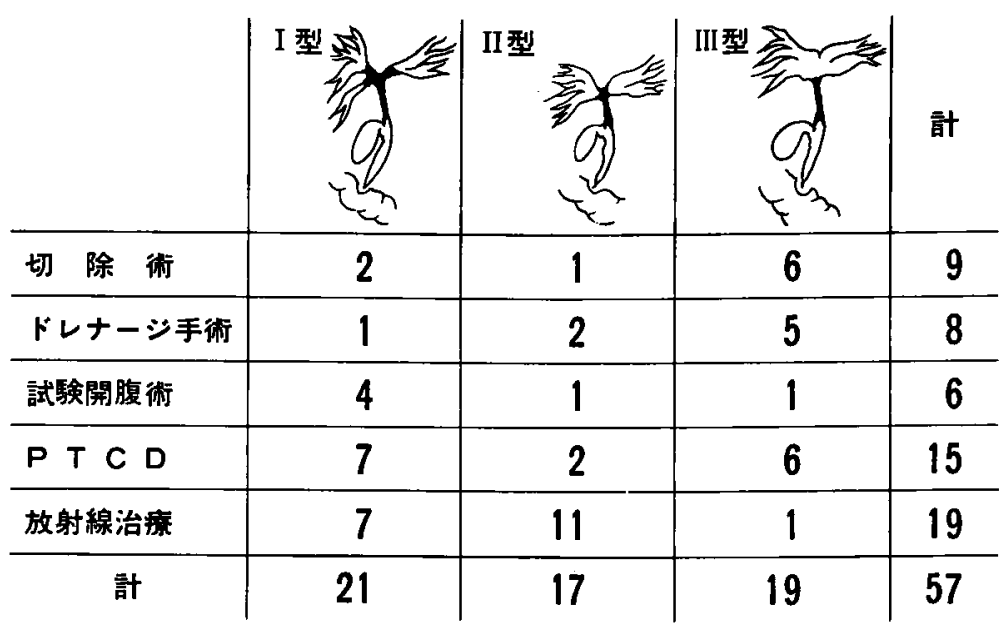

癌腫の占居部位から上部胆管癌を 3 群に大別すると， I 型は，左右肝管合流部から肝内胆管の第 2 分岐あるい はそれ以上の進展をみるむので，21例，36\%，I型は， 左右肝管に癌の進展をみるも第 2 分岐に至ら好むので, 17例，30\%，III型は，棇肝管に存在するもので，19例， $34 \%$ である. 切除例は，I型に 2 例，II 型に 1 例， II 型 に 6 例である.

\section{II 切除可能性と術式}

\section{1）切除可能性の判定}

肝切除を伴わない胆管切除における切除可能性は，(1) 腫痘胆管が周囲組織, 特に, 肝動脈, 門脈之剥離らるか どうか, (2) 肝切除を伴わなくとる健常な肝側胆管の切 除断端が党られるかどうか，に大きく依存する。

\section{2）手術々式}

上腹部正中切開あるいは右肋弓下切開にて開腹.

脺頭十二指腸の授動 (Kocher の授動) と膆後部リン パ節廓清. 肝十二指腸勒带を左下方に繁引させ緊張をか けながら，まず，十二指腸緑で朋十二指腸勒带前面に切 開を加え, 肝側付着部亡で剥離, 摘除する. 胆管腫瘤部 での痣着が強い場合はその部まででとどめる.この剥離 は，胆管と肝動脈を残し（門脈は両者の背側にあるので ここではふれない）他は全て摘除するように行う。

脺上縁において，総胆管を全周にわたって周囲組織か ら制離, 露出させ, 脺後面に入りこむ部で胆管を切除寸 る. 十二指腸側胆管の切断後は，通常 atraumatic 00 000で連続縫合で閉鎖する.

総肝動脈の露出とリンパ節廟清を行ない, 更に, 固有
肝動脈を露出させ Taping を行なう、総胆管 Taping 部 の背側で，門脈を露出ざせ，それに Tape をかけてお $<$.

肝動脈の Taping を利用し，周囲リンパ節遊清, 胆管 との䟝離を進め，右・左肝動脈に Tape をかけ，肝内 に至るまで動脈を遊離させる.この際，胆管切断端を鎮 子でしっかり把持し，上下，あるいは左右に率引しなが ら行なうと操作が容易である. 胆衰動脈は基始部で結热 切断. 右胃動脈す通常切断した方が操作が容易となる. 又, リンパ節摘出の関係上，胃十二指腸動脈も結禁切断 することがあるが, case by case である.

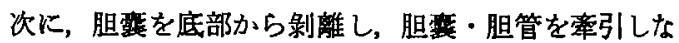
がら，門脈との虽離を進め肝門部に至る。ここの際，門脈 にかけた Tapeを利用し、リンパ節, リンパ管は勿論, 神経組織などを含む結合織を閒脈から完全に制離させ, 摘出する胆管側に付着させながら操作を進める. 要は, 切除した時点で肝十二指腸靱帯部には，固有肝動脈とそ れにつつくく右・左肝動脈，門脈，十二指腸側胆管断端だ けか浌るような状態が望むしい。

左右肝管分岐部が，肝実質，肝動脈 門脈から䟝離さ れたら，左下方に牽引しながら切除線を決める，腫瘤か らはなれ茟常と思われる部から $5 \mathrm{~mm}$ 以上肝側で切離す るのを原則とし，断端を凍結標本に提出する. I 型で は，左右肝管を更に鈍的に剥離（あるいは鋭的に）しな がら，第 2 分岐をこして肝内胆管を追跡䟝離して行く. 胆管切断に際しては，切除線より約 $1 \mathrm{~mm}$ 肝側胆管に Dexon 000針を 2 針つつかけ支持系とする. 
表 2 上部胆管珵切除例 (1)

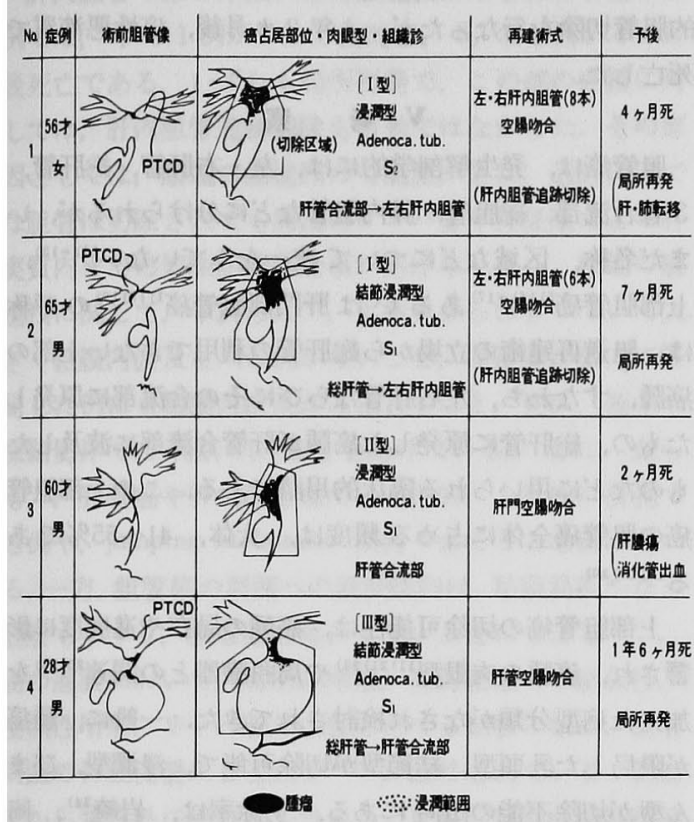

胆道再建は，肝内胆管と空腸を Roux Y 吻合で行な

5. 胆道減圧チューブは，PTCDチューブをそのまま留 固，あるいは経肝的チューブを設固し行なう.

\section{IV 上部胆管癌切除例と予後}

上部胆管癌に対する切除術式は，いずれも肝切除を伴 わない胆管切除で， $ち$ 万 2 例は肝内胆管追跡切除， 1 例 は脺十二指腸合併切除である（表 2，3）。
表 3 上部胆管癌切除例 (2)

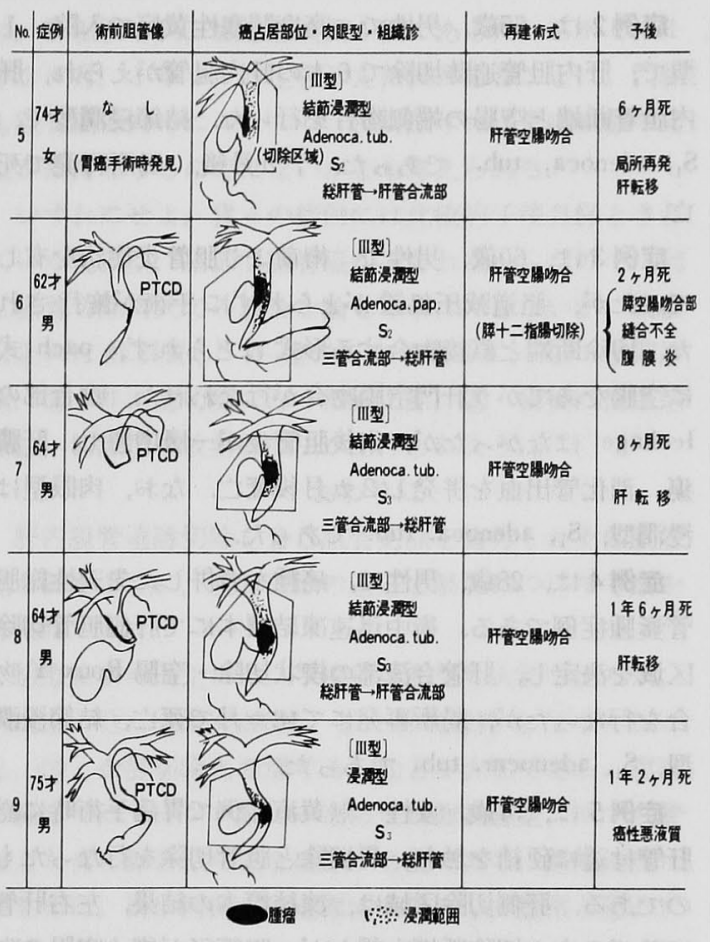

症例 1 は, 56歳, 女性で, 高度閉塞性黄疸にて他医に 3 カ月問入院後, 当科に紹介されたものである. PTC では，隀瘍は肝管合流部から進展した I 型と考えられ， 肝実質内まで肝内胆管を追跡切除した，8本の切除断端 を Roux Y 型にるち上げた空腸とそれぞれ 端側吻合を 行なった（図 1). 肉眼型は, 浸潤型, $\mathrm{S}_{2}$, 組織学的には adenocarcinoma tubulare であった. 術後 3 週で退院し

図 1 上部胆管澏（追跡切除例）

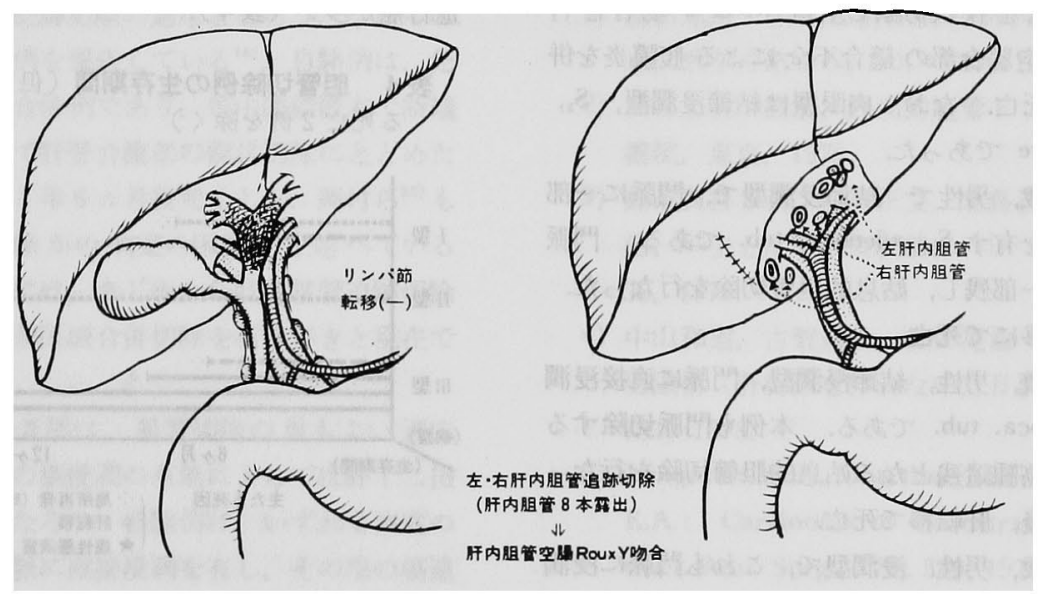


たが，4カ月後，局所再発，肝・肺転移で死亡.

症例 2 は, 65歳, 男性で, 高度閉塞性黄㡺で入院. I 型で, 肝内胆管追跡切除で 6 本の肝内胆管がえられ, 肝 内胆管断端々空腸の端側吻合を行った．結節浸潤型で, $\mathrm{S}_{1}$, adenoca. tub. であった. 7 カ月後, 局所再発で死 亡.

症例 3 は, 60歳, 男性で 術前より胆管炎症状を有し ていたが，胆道減圧処置がとられずに手術が施行され た. 切除断端と直接吻合する形式はとられず，pach 式 に空腸をあてがう肝門空腸吻合が行なわれた。伆合部の leakage はなかったが，術後胆管炎が一層增悪し，肝膿 瘍，消化管出血を併発し 2 カ月後死亡.なお，肉眼型は 浸潤型， $\mathrm{S}_{1}$, adenoca. tub. であった。

症例 4 は，28歳，男性で，癌腫を合併した先天性総胆

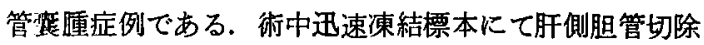
区域を決定し，肝管合流部の楔状切除・空腸 Roux Y 吻 合を行なったが，局所再発にて18力月で死亡，結節浸潤 型, $\mathrm{S}_{1}$, adenocar. tub. であった.

症例 5 は，74歳，女性 無黄疾症例で胃癌手術時に総 肝管付近に硬結を触れ，胃切除々胆管切除を行なったる のである. 肝側切除区域は, 凍結標本の結果, 左右肝管 に及び 3 本の切除断端を得たが，胆管径が細く空腸の吻 合が十分に行なえずシリコンチューブを splint にした不 完全吻合であった，術後格別合併症もなく 4 週で退院し たが，7カ月後局所再発，肝転移で死亡. 結節浸潤型, $\mathrm{S}_{2}$, adenoca. tub. であった.

症例 6 は，62歳，男性で，高度閉塞性黄疸にて入院し たものである. 当初， 3 管合流部付近の癌腫と考え膡十 二指腸切除を施行. 切除標本にて総肝管癌と判明, 術中 倲結標本にて肝管合流部付近むで癌浸潤のあることがわ かり，肝門部胆管を楔状切除し空腸 Roux $Y$ 吻合を行 った，術後，膵空腸合部の䋖合不全による腹膜资を併 発し， 2 力月後死亡. なお, 肉眼型は結節浸潤型, $\mathrm{S}_{2}$, adenoca. papillare であった.

症例 7 は, 64歳, 男性で 結節浸潤型で, 門脈に一部 direct invasion を有す $S_{3}$, adenoca. tub. である. 門脈 漫潤部の癌腫を一部䂝し，姑息的胆管切除を行なった. 8 力月後, 肝転移にて死亡.

症例 8 は，64歳，男性，結節浸潤型，門脈に直接浸潤 を有す $S_{3}$, adenoca. tub. である. 本例む門脈切除する ことなく，一部癌渪選残となる姑息的胆管切除を行なっ た. 1 年 6 力月後, 肝転移で死亡.

症例 9 は，75歳，男性. 浸潤型で，これも門脈に浸潤
する $\mathrm{S}_{3}$, adenocar. tub. である. 上記 2 例と同様，姑息 的胆管切除を行なったが，1 年 2 カ月後, 癌性悪瘦質で 死亡した.

\section{$\mathbf{v}$ 察}

胆管癌は, 発生解剖学的には, 左・右肝管, 総肝管, 3 管合流部，総胆管，勑内胆管などに分けられるが，い まだ名称，区域などについて統一をみていない111133．

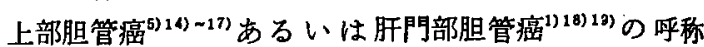
は，胆道再建術の立場から総肝管の利用できない上部の 癌腫，すなわち，左右肝管ならびにその合流部に原発し たもの，総肝管に原発した癌腫か肝管合流部に波及した わのなどに用いられる臨床的用語である。この上部胆管 癌の䏣管癌全体に占める頻度は，大体，41 55\%であ

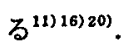

上部胆管癌の切除可能性は，癌腫の局在や進展度に影

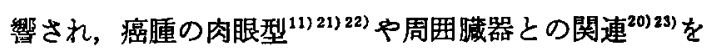
加えた病型分類がなされ検討されてきた。一般に，看瘍 が限局した乳頭型，結節型が切除可能で，浸潤型，びま 几型が切除不能の傾向にある, 切除率は, 岩崎 ${ }^{24)}$, 岡 村 ${ }^{25)}$ らの58〜83.3\%は別として，一般に，14.3\%から40 \%の間にあると言之るる(2) 15) 19920) 26).

上部胆管の手術々式には，Fortner $5^{27)}$ の肝全摘・肝 移植を除いては，胆管切除と肝葉切除の 2 つに分けら れ，それぞれ適応が述べられている. 胆管切除の適応に ついては，総肝管に限局又は左右肝管にわずかに浸潤し た程度の乳頭型，結節型を゙，更に，血管に異常所見が ないるのでは肝内胆管の第 2 分㞳まで及ばないるのまで 適応とされている ${ }^{24)}$ ，自験例は，いずれも肉眼型は結節 浸潤型, あるいは浸潤型で，なかには，門脈に直接浸潤 を有する例があり，癌占居部位，淮展度からみて高度の 進行癌が多い(表 4 ).

表 4 胆管切除例の生存期間（但し，手術に関連す る死亡 2 例を除く)

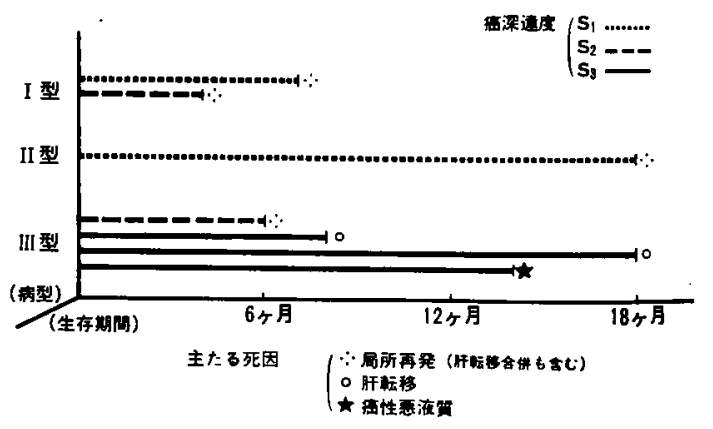


肝内胆管の第 2 分岐にまで癌進展がみららた I 型の 2 例では, $\mathrm{S}_{1}$ の 1 例が7 カ月後死亡, $\mathrm{S}_{2}$ の 1 例が 4 力月 後死亡である. いずれる局所再発で, この部の癌腫に対 しては, 肝内胆管追跡切除る有奻ではなかった. その原 因としては，断端の癌遗残の可能性，更に，追跡切除で は肽管は切除されても周囲のリンパ管や神経束などの肝 実質内までの切除が困難な事があげられよう. 断端の癌 遺残に関して，中沢らは ${ }^{28)}$ ，主病巣からひきつついて大 きく粘膜内波及をみる例が多いこと, 深達度が壁内に限 局した例にも粘膜内波及がみられること, 更に, 術中の 凍結切片での判断の困難性をあげている，また，金ら $b^{29)}$ ，肝管癌や肝内胆管癌では直接的，上行性に浸潤す る例や，jumping metastasis が時々あることをあげてい る.一方, 胆管癌の周囲への浸潤傾向は，粘膜筋板がなく 筇層すうすく，胆管壁自体からすいことにもよる 癌の進展において, 局所的堌殖, 周用組織八の膨張性, 浸潤性增殖、リンパ管や血管を介する転移の他に，胆管 周用の神経侵蒩による因子 ${ }^{3234)}{ }^{34}$ 注目されている. 胆管 壁から箩膜外に癌進展が及らと, 比較的早期に神経侵襲 をきたしやすく ${ }^{322}$ ，神経周用リンパ唒を経て癌細胞が進 展する ${ }^{33)}$. 従って, 切除に際しては, リンパ節のみなら ず神経組織をす含む結合織の徹底的廓清が必要で，それ が根治性を高めるもととなる. しかし，肝内胆管第 2 分 岐まで癌浸潤が及ぶ I 型では, 胆管切除では肝側の廓清 が不十分であり, 肝葉切除の適応を考えざるをえない. 肝葉切除る, 癌腫が肝門部を中心としているすのである ため, 内側前区域の切除が必須であり，左葉切除か拡大 右葉切除か内側前区域切除かの選択は, 癌進展度ととも

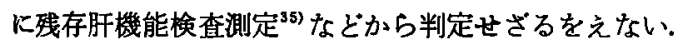

左右肝管に癌進展をみるむ第 2 分岐に至らないII 型 は, 通常, 肝内胆管追跡切除の適応となろ5. 小坂らは 4 年 3 カ月生存した例を報告している ${ }^{36)}$. 自験例は，先 天性総胆管栾腫の癌合併例であり, 術中倲結標本で断端 癌遺残なしとのことで肝管合流部の楔状切除にとどめた ところ, 局所再発で 1 年 6 カ月後死亡した. 岡村ら ${ }^{25)}$ 女 治瘾切除か非治瘁切除かの判定の困難性を述へている が,このような II 型には, あじめから肝内胆管追跡切除 か, あるいは，内側前区域合併切除を行らべきと現在で は考えている.

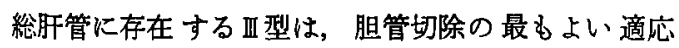
で, 三管合流部以下の癌浸潤の有無によっては膵十二指 腸合併切除も適応となろ5，自験例は，いずれも高度の 進行癌で， 3 例が門脈に直接浸潤を有し，その部の癌遺
残のまま姑息的切除を行なったるのである，主たる死因 は，肝転移 2 例，癌性悪液質 1 例であった. しかし， 1 年 2 カ月， 1 年 6 カ月生存しえた例があることは，門脈 も胆管癌と同時に en block に切除すれば更に成績の向 上が期待しらるのではないかとも考えられる.

いずれにせよ，我々の症例には比較的予後良好とされ ている乳頭型，結節型胆管癌がみられなかったので，同 じ胆管切除術式での成否を論じる事はできないか，成績 向上には蜂㮌賀ら゙゙が述べているように，(1) 早期診 断，(2) 非治痁切除でなく治病切除，(3) 術後の抗癌剤 療法, 切除後の放射線療法があげられよ5.

\section{VIおわりに}

肝内胆管追跡切除を含む胆管切除を施行した上部胆管 癌 9 例を中心に，胆管切除の適応と限界について考察を 加之た.

治療成績の向上には，早期癌の発見も大切であるが， 術式上, (1) 徹底的廍清, (2) 断端遣残をなくするこ と. (3) 合併切除む考慮する,などが大切である. 廓清 に関しては,リンパ節のみならず周囲神経束, リンパ管 などを含め結合織の完全摘除が必要である．断端遗残に 関しては，術中何回も迅速標本を提出し，健常と思方れ る部より䄪 $5 \mathrm{~mm}$ 以上はな机て切除することである. 型 別には，I 型には，拡大右葉切除，左葉切除，内側前区 域切除など肝切除を選択適応することが必要である。 II 型では，肝内胆管追跡切除あるいは内側前区域合併切除 の適応を考える. 門脈への浸潤に関しては, en blockに 門脈合併切除考慮すべきのと考える。

（本論文の要旨は，第40回日本臨床外科医学会総会に て報告したものである。）

\section{女 献}

1) 高田忠敵：肝門部胆管癌の外科治療上の問題 点, 医学のあゆみ, $101: 745,1977$.

2) 高田忠敬 : 図解, 释皮的胆管ドレナージ, 医学 書院, 東京, 1978.

3) 蜂須賀喜多男, 暒田正文, 北島正晃 : 上部胆管 癌, 一主として手術成績について一, 外科40： $38,1978$.

4) 中山和道, 古賀道弘, 吉田晃治 : 肝門部胆管癌 切除術 (肝切除を伴わない), 日消外会誌：79, $783,1978$.

5) Longmire, W.P., Mcarthur, M.S. and Bastounis, E.A.: Carcinoma of the extrahepatic biliary tract. Ann. Surg., 178: 333, 1973. 
6) Kelly, K.A.: Successful resection of adenocarcinoma of junction of right, left, and common hepatic biliary ducts. Mayo. Clin. Proc., 47: 48, 1972.

7) Klippel, A.P. and Shaw, R.B.: Carcinoma of the common bile duct. Arch. Surg., 104: 102, 1972.

8) Quattlebaum, J.K. and Quattlebaum, J.K. Jr.: Malignant obstruction of the major hepatic ducts. Ann. Surg., 161: 876, 1965.

9) Cady, B. and Fortner, J.G.: Surgical resection of extrahepatic bile duct cancer. Ann. J. Surg., $118:, 104,1969$.

10) El-Domeiri, A.A., Brasfield, R.D. and O'Quinn, J.L. : Carcinoma of the extrahepatic bile ducts. Ann. Surg., 169: 525, 1969.

11) Sako, K., Seitzinger, M.D. and Garside, E.: Cardnoma of the extrahepatic bile ducts, review of the literature and report of six cases. Surg., $41: 416,1957$.

12) Thorbjarnarson, B.: Carcinoma of the bile ducts. Cancer, 12: 708, 1959.

13）水本龍二, 横田 峻: 胆管, 胆道系の腫湯一発 生部位別にみた特徽と手術成績一肝藏, 17 ： 133, 1976.

14）本庄一夫, 水本龍二 : 墨性腫瘍による閉塞性黄 疸の外科的治療，医学のあゆみ，86：643， 1973.

15）土屋原一, 伊藤俊战, 角田 司：外科からみた 胆道癌, 胃と腸, $12: 733,1977$.

16) 羽生富士夫, 高田忠敬, 浜野恭一：悪性腫焬と 黄疾, 治療, $57: 937,1975$.

17）都築俊治, 植草 奏: 胆管癌治療上の問題点に ついて, 肝葴17:137, 1976.

18）岩崎洋治, 佐藤 博, 岡村隆夫 : 肝門部胆管癌 の切除例について, 日消外会誌，8:28，1975.

19）木南義男，宮崎逸夫，高嶋茂樹：肝門部胆管癌 の手術成績と型分類，日消外会誌，11:379, 1978.

20) 後藤明产, 岩堤慶明, 林 淳治: 胆管癌の外科 的治療一特に発生部位よりみた切除可能性の榆 討一日消外会誌，9：301，1976.
21) Strohl, E.L., Reed, W.H. and Differnbaugh, W.G.: Carcinoma of the bile ducts. Arch. Surg., 87: 567, 1963.

22）宮崎逸夫, 坂東平一, 西田良夫他 : 胆管癌一特 にその発生部位並びに形状を中心に一日本医事 新報, $2351: 3,1969$.

23）营原克彦, 黒田 慧, 田島芳雄 : 胆管癌および 膨大部癌, 臨外, $27: 339,1972$.

24) 岩崎洋治, 佐藤 博, 岡村隆夫 : 肝門部胆管癌 に対寸る手術々式，手術30：795，1976.

25) 岡村隆夫, 佐藤 博, 岩崎洋治 : 肝門部胆管癌 の治療一特に切除例を中心に一外科, $38: 867$, 1976.

26）满山育三, 今野修光, 田代正記 : 胆道癌の転移 様式，臨床成人病， $6: 1199 ， 1976$.

27) Fortner, J.G., Kallum, B.D. and Kim, D.K.: Surgical management of carcinoma of the junction of the main hepatic ducts. Ann. Surg., 184: $68,1976$.

28）中沢三郎, 佐野 博, 木本英三 : 粘膜面に批け る胆管癌の広がりについて，日消病会誌，75： $1370,1978$.

29）金 清一, 戸部隆吉, 高三秀成 : 胆道系癌の臨 床病理学的研究一病理学的予後因子の検討を主 として一日消病会誌, $76: 684,1979$.

30) 永光慎吾 : 胆道系の早期癌について, 月消病会 誌 $67: 64,1970$.

31）羽生富士夫, 鈴木博孝, 高田忠敬 : 胆道癌一初 期癌, 早期癌一現代の診療, $19: 184,1977$.

32）長与健夫, 村上信之, 松岡幸彦: 胆萑癌, 胆管 癌扰よび脺管癌の局所神経侵䠃について，癌の 臨床, $22: 1406,1976$.

33）岸野泰雄 : 浸潤転移からみた胆道癌剖検例の検 討, 癌の臨床 $22 ： 464,1976$.

34) Fahim, R.B., McDonald, J.R. and Richard, J.C.: Carcinoma of the gallbladder, a study of the modes of spread. Ann. Surg., 156: 114, 1962.

35) 高崎 健：肝切除術における残存肝機能推湘法 の考案, 日外会誌, $79: 1526,1978$.

36) 小坂 進，中川 正: 老年者に拈ける䏣道癌の 臨床, 臨外 $29: 607,1974$. 